\title{
NITROGEN, PHOSPHORUS AND ORGANIC CARBON IN MAIN RIVERS OF THE WESTERN GREECE
}

\section{OVEZIKOGLOU \\ M. LADAKIS \\ M. DASSENAKIS* \\ M. SKOULLOS}

\author{
University of Athens \\ Department of Chemistry \\ Laboratory of Environmental Chemistry \\ Panepistimiopolis 15771 Athens
}

Selected from papers presented at the $8^{\text {th }}$ Conference on Environmental Science and Technology, 8-10 September 2003, Lemnos, Greece. *to whom all correspondence should be addressed: tel/fax: +(30)-210-7274269 e-mail: edasenak@cc.uoa.gr

\begin{abstract}
Results of a monitoring project for the water quality of three important rivers of western Greece (Acheloos, Louros and Acherontas) are presented in this paper. The results include the concentrations as well as the temporal and spatial distributions of nitrates, nitrites, phosphates, ammonia and dissolved organic carbon for a period of twelve months (October 2002 to September 2003). Monthly samplings took place in four sampling sites at the rivers Acheloos and Louros and two at the river Acherontas. The samples were analyzed by standard spectrophometrical methods.

According to our measurements, Louros is the most polluted river as it concerns nitrogen compounds, probably due to the increased human activities in its catchment area. It also occasionally accepts pollutants from the small stream of Vossa.

Although Acheloos is the biggest and most important river for the whole territory, it seems not to be heavily polluted. The chemical parameters level, indicates the enrichment of its water in nutrients, from the water of Lisimahia lake that enters the river through the water lock of Dimikos. No significant inflow of pollutants was observed in river Acherontas, since no remarkable spatial variation recorded.
\end{abstract}

KEYWORDS: River, Acheloos, Louros, Acherontas, Nutrients, TOC

\section{INTRODUCTION}

Rivers are very important for human life. Many cities and civilizations rose and developed along their sides. Rivers are used for irrigation, com- 
mercial transportation and also for entertainment and tourist activities. Human activities like industry, agriculture,cattle-breeding,waste disposal, establishment of hydroelectrical dams, etc, affect the quality of water and the environment of the catchment area of many rivers.

The sustainable management of riverine systems requires a holistic, river-basin scale evaluation of environmental problems which shall provide the appropriate scientific framework for managing the impacts of human activities. Data from various systems are needed to better assess natural variability and to provide a basis for differentiating natural from polluted level concentrations. The understanding of the chemical processes taking place in rivers, polluted by a variety of sources, is of great importance for the improvement of their water quality. These processes respond strongly to changes in major physicochemical variables like $\mathrm{pH}$, redox conditions or ionic strength and also to hydrodynamic processes (Olmez et al., 1994; Dassenakis et al., 1998).

The recognition (in the early sixties), of the environmental degradation of riverine systems, resulted to studies about the origin and the behaviour of pollutants mainly in the heavily polluted rivers of the industrialised countries of North Europe, North America, and former USSR. During the same period the study of small riverine systems was rather limited, although their ecological importance is considerable, since some of them are also heavily polluted and have great importance for the local populations. In most Mediterranean countries there is no systematic monitoring of the quality of surface waters although a lot of pollution problems have been observed mainly due to the lack of the proper management. In Greece a network of State Laboratories has been recently established for the monitoring of main Greek rivers but it is not yet completed (Greek Oceanographers Association, 1994). Most reliable information for rivers flowing into the Mediterranean comes from potentially contaminated rivers in the NorthWestern Basin, such as the Rhone, Ebro, Arno, Tiber. Etc (Jeftic, 1990; Coste and Raimbault, 1993; Guieu et al., 1991; UNEP, 1993).

The study of the levels and fluctuations of nutrients and organic load in rivers is of great environmental significance. Such studies concerning rivers that discharge into the Mediterranean are particularly important as some of them may cause the develop- ment of eutrophication phenomena. The effects of these pollutants are indirect in comparison to heavy metals or pesticides; e.g. severe organic pollution of rivers may lead to oxygen depletion and high ammonium levels, conditions that are unfavourable for benthic invertebrates and fish (EEA 1994).

In this paper, results of a study concerning the pollution of three rivers in western Greece (Louros, Acheloos and Acherontas), affected by human activities, are presented. Western Greece has relatively small cities, a few light industries and extensive agricultural and cattle-breeding activities. The water potential of this area is very important, as the rainfall in Western Greece is the highest in comparison to all other areas of the country.

\section{The studied rivers}

River Acheloos, in Western Greece is one of the main Greek rivers. It has a drainage area of 5350 $\mathrm{km}^{2}$ and a mean flow (measured $50 \mathrm{~km}$ upstream of the river mouth) of $140 \mathrm{~m}^{3} \mathrm{~s}^{-1}$. Large hydroelectric dams, at the upper part of the river, have affected the seasonal fluctuation of the river flow which after the hydroelectric dam of "Stratos" (the last along the river bed, $7.5 \mathrm{~km}$ from the river mouth) is $42 \mathrm{~m}^{3} \mathrm{~s}^{-1}$. In some periods the river flow falls to $10 \mathrm{~m}^{3} \mathrm{~s}^{-1}$ as increased water quantities are used for irrigation of about $370 \mathrm{~km}^{2}$ of cultivated land. The flow of Acheloos depends mostly on dams than on seasonal rainfall; higher flow is reported during summer, because of the increased demand for electrical power, than winter or spring (National Statistic Service of Greece, 1996; The Greek Ministry of Agriculture, 2001; 2003)

The river Acheloos does not receive any direct urban or industrial waste water discharges. However it receives the land washout and runoff of a relatively large catchment area cultivated with various plants. Acheloos affects the distributions of nutrients in the entire North-Western section of the Patraikos Gulf and in the nearshore part of the Ionian Sea, acting as a significant nitrogen source, attributed to the washout of fertilisers (Scoullos et al.,1985; 1992a). It also affects the hydrology of the neighbouring Messolonghi lagoon, which is under the protection of the Ramsar convention (Bonazountas et al., 1992). A large project for the divertion of about one third of river water to Pinios river at Thessaly (Central Greece) has been planned for hydroelectric energy production and irrigation purposes. The project 
is under development although there is a significant debate between Greek Government and Environmental non Governmental Organisations (NGO's) about the environmental impacts of the divertion on the hydrology of the catchment area of the Acheloos and the riverine and estuarine ecosystems (Greek NGO's, 1993; The Greek Ministry for the Environment, 1989)

The river Louros has a length of about $75 \mathrm{~km}$ and an average flow of about $10.6 \mathrm{~m}^{3} \mathrm{~s}^{-1}$ that ranges between $5 \mathrm{~m}^{3} \mathrm{~s}^{-1}$ in the summer and $20 \mathrm{~m}^{3} \mathrm{~s}^{-1}$ in winter. Its water irrigates about $120 \mathrm{Km}^{2}$ of cultivated area and supply a hydroelectric dam of $10 \mathrm{MW}$ electric power. At the estuaries of Louros there are lagoons such as Tsoukalio, Rodia, Logarou, and Tsopeli which are important protected wetlands with international reputation, designated under the Ramsar Convention and the European Communities' Legislation. About $2.5 \%$ of its catchment area of approximately $800 \mathrm{~km}^{2}$ is cultivated. In the same region more than 100 large and small agricultural industries and fish farms operate (Koussouris et al., 1989b). The average pollution loads discharged daily by them in the catchment basin of the Louros river, estimated by Ziogas et al. (1982) are: $\mathrm{BOD}_{5}: 653.5 \mathrm{~kg}$, COD: $8743.5 \mathrm{~kg}$, S.S.: $8337.5 \mathrm{~kg}, \mathrm{~N}_{2}: 471.3 \mathrm{~kg}, \mathrm{P}_{2} \mathrm{O}_{5}: 3.0 \mathrm{~kg}, \mathrm{P}: 90.0 \mathrm{~kg}, \mathrm{~K}_{2} \mathrm{O}:$ $120.4 \mathrm{~kg}, \mathrm{~K}: 98.6 \mathrm{~kg}, \mathrm{Cu}: 1.3 \mathrm{~kg}, \mathrm{Zn}: 7.8 \mathrm{~kg}, \mathrm{Fe}: 4.3 \mathrm{~kg}$, $\mathrm{Mn}: 2.1 \mathrm{~kg}$.

The length of river Acherontas is about $50 \mathrm{~km}$ and its flow range from $4 \mathrm{~m}^{3} \mathrm{~s}^{-1}$ in the summer to 25 $\mathrm{m}^{3} \mathrm{~s}^{-1}$ in the winter having an average of about $11.4 \mathrm{~m}^{3} \mathrm{~s}^{-1}$. Its waters irrigate $85 \mathrm{~km}^{2}$ of cultivated area. It is also affected by human activities. The construction of small dams and the sand collection from its sides has changed its characteristics during the last decade. River Acherontas and its estuaries are subsumed at Natura 2000 network.

\section{MATERIALS AND METHODS}

The studied areas and the sampling sites are presented in figures 1 and 2. Four stations were selected at Acheloos and Louros rivers and two at Acherontas. The locations of the sampling stations were chosen according to the existing information and analytical data of previous periods from Ministry of Agriculture and General State Laboratory. Monthly samplings occurred from October 2002 to September 2003.

Dissolved $\mathrm{O}_{2}$, temperature, conductivity, and $\mathrm{pH}$ were measured in situ with Y.S.I.-63 portable $\mathrm{pH} /$ temp/cond/sal meter and Y.S.I.-57 portable
DO/temp meter. Water samples were taken by horizontal HDPE Hydro-Bios sampling bottles and were kept in the refrigerator. A few drops of saturated $\mathrm{HgCl}_{2}$ were added as preservative. In the laboratory the samples were filtered through $0.45 \mu \mathrm{m}$ preweighed Millipore filters. All sample handling was carried out in a clean box to prevent contamination. Spectrophotometry was used for the determination of nutrients according to the Standard Methods for the Examination of Water and Wastewater (American Public Health Association, 1985). Sulfanilamide and a-nafthyl-ethylen-diamine were the reagents used for the nitrite determination since nitrates were reduced to nitrites by the use of a reduction column full of cadmium pellets. The Indophenol blue method was used for the determination of ammonia. Phosphates were determined by the method of molybdene blue with ascorbic acid as reducing reagent. Silicates ware determined by the molybdosilicate method. A Varian, Cary $1 \mathrm{E}$ double beam spectrophotometer and a Bran+Luebe nutrient autoanalyser were used for the measurements (Grasshof 1997; Skoullos 1992b; Siskos 1992). Dissolved organic carbon is oxidized (high temperature catalytic oxidation) into $\mathrm{CO}_{2}$, which is measured with a non-dispersive infrared (NDIR) detector in a Shimadzu TOC (Total Organic Carbon) 5000 Analyzer.

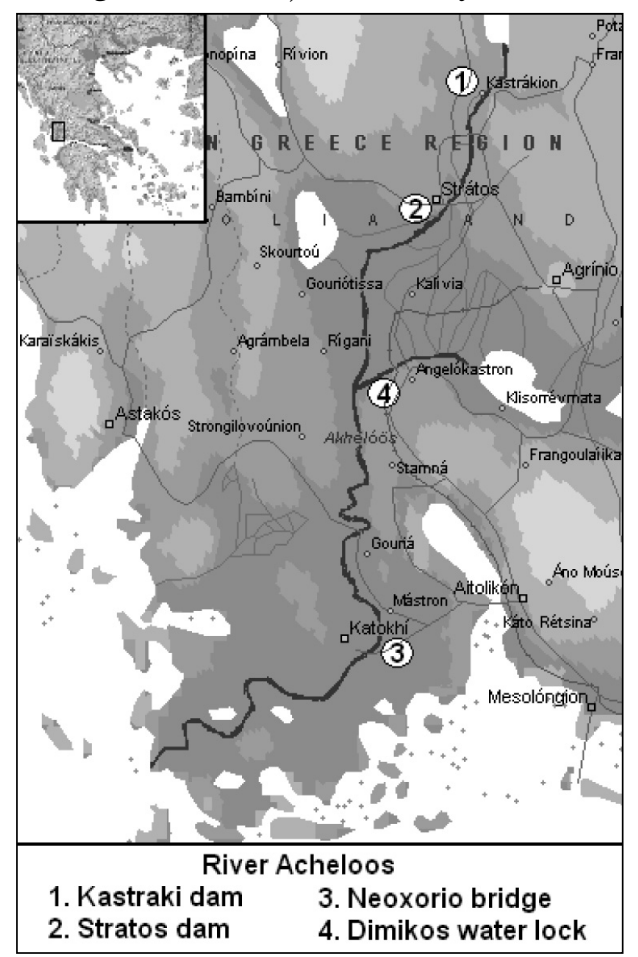

Figure 1: The area of Acheloos 


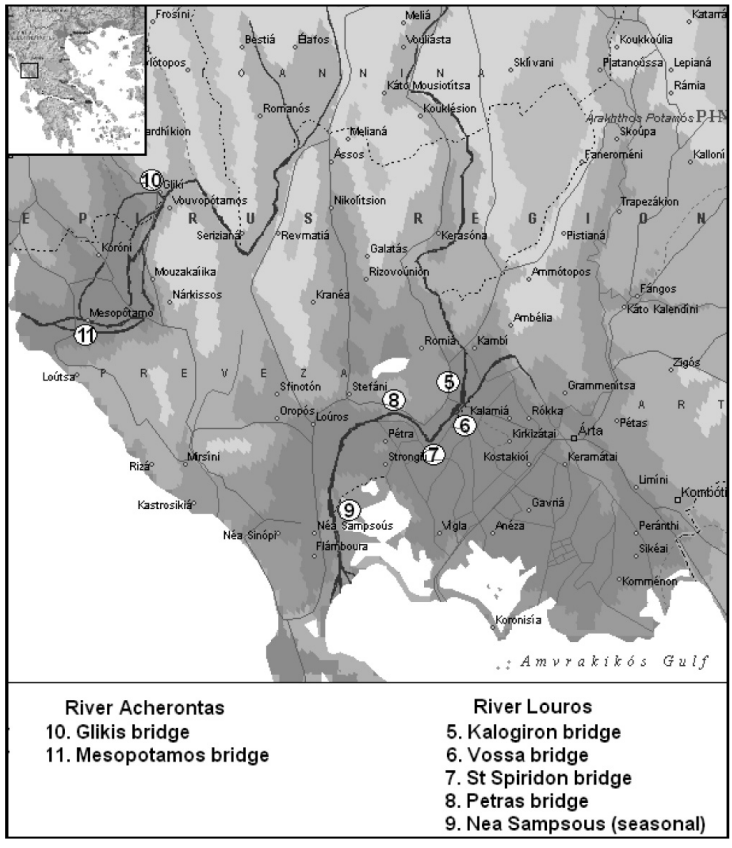

Figure 2: The area of Louros and Acherontas

\section{RESULTS AND DISCUSSION The river Acheloos}

Seasonal mean values of nitrogen and phosphorous compounds as well as dissolved organic carbon (DOC) are presented in Table 1.

Values of Table 1 indicate that the concentrations of all nitrogen forms were increased during autumn (with the exception of ammonia which is increased in winter), and decreased during spring and summer. This fluctuation follows the fertilization activities, which, in this area, mostly occur in autumn. The seasonal mean concentrations of phosphates were similar with the exception of winter when very low values were detected. Decreased values of organic nitrogen, organic phosphorous and dissolved organic carbon, were measured during the warm period of the year as the increased temperature favours the organic matter decomposition via bacteria.

The annual mean values of nitrogen and phosphorous compounds as well as dissolved organic carbon, at the sampling stations of Acheloos river, are presented in Table 2. A general increasing trend was observed downstream.

The distribution of phosphates, nitrites, nitrates and DOC along the river, indicate that the water of lake Lisimahia entering the river through the water lock of Dimikos, occasionally enriches the riverine water in these compounds. The case of
February 2003 that is presented in Figure 3, is a characteristic example of this influence.

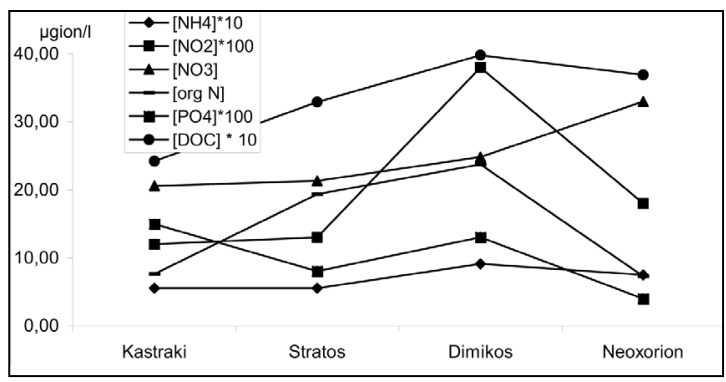

Figure 3: Concentration of nutrients and DOC along Acheloos during February 2003

The unnatural fluctuation of the river flow, due to dams, leads to the abnormal fluctuation of the concentration of some nutrients. For example, the highest value of ammonia $\left(17.1 \mu\right.$ gat $\left.\mathrm{N} \mathrm{l}^{-1}\right)$ was measured in the sampling point of Stratos dam when the flow was only $0.03 \mathrm{~m}^{3} \mathrm{~s}^{-1}$ (January 2003). The very next month when the river's flow was $18.18 \mathrm{~m}^{3} \mathrm{~s}^{-1}$, the ammonia concentration was only $0.55 \mu$ gat $\mathrm{N}^{-1}$.

Nitrates are the prevalent form of nitrogen, being the $56 \%$ of the total, followed by the organic nitrogen compounds (39\%). The contribution of nitrites $(1 \%)$ and ammonia (4\%) to the total is very low. On the other hand, organic forms of phosphorous, being the $61 \%$ of the total, dominate over inorganic forms.

Although all possible pairs of chemical parameters have been tested in order to find out possible correlations, poor results were obtained. This fact indicates that Acheloos is probably polluted occasionally by diffused sources than systematically by point sources. A fare correlation found between ammonia and nitrates and shown in Figure 4, may be attributed to the composition of fertilizers used in this area.

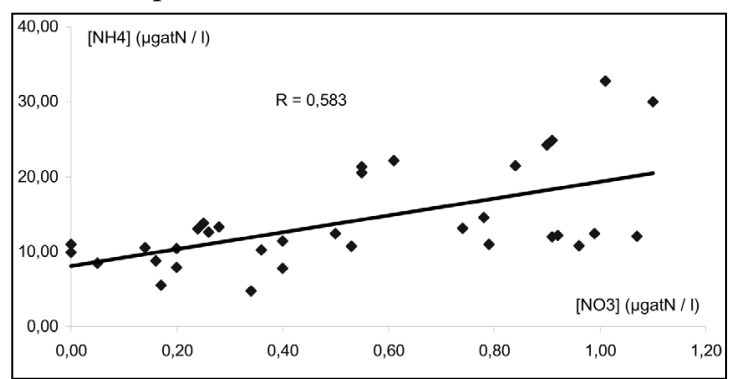

Figure 4: Correlation between $\left[\mathrm{NO}_{3}^{-}\right]$and $\left[\mathrm{NH}_{4}{ }^{+}\right]$in the river Acheloos.

Some previous values of nutrients and DOC concentration in river Acheloos are presented in 
Table 1. Seasonal mean values from all sampling stations at river Acheloos

\begin{tabular}{|c|c|c|c|c|}
\hline & Autumn 2002 & Winter 2003 & Spring 2003 & Summer 2003 \\
\hline$\left.\overline{\left[N_{4}+\right.}\right]\left(\mu\right.$ gat $\left.N l^{-1}\right)$ & 1.48 & 2.37 & 0.73 & 0.44 \\
\hline$\left[\mathrm{NO}_{2}^{-}\right]\left(\mu \mathrm{gat} N l^{-1}\right)$ & 0.30 & 0.21 & 0.22 & 0.18 \\
\hline$\left[\mathrm{NO}_{3}^{-}\right]\left(\mu \mathrm{gat} N l^{-1}\right)$ & 19.9 & 16.5 & 17.8 & 11.3 \\
\hline $\operatorname{Org} N\left(\mu g a t N l^{-1}\right)$ & 15.8 & 11.3 & 7.8 & 12.2 \\
\hline TotN ( & 37.5 & 30.4 & 26.5 & 24.1 \\
\hline$\left[\mathrm{PO}_{4}^{3-}\right]\left(\mu\right.$ gat $\left.P l^{-1}\right)$ & 0.15 & 0.05 & 0.15 & 0.16 \\
\hline $\operatorname{Org} P\left(\mu\right.$ gat $\left.P l^{-1}\right)$ & 0.31 & 0.16 & 0.19 & 0.16 \\
\hline TotP ( $\mu$ gat P l-1) & 0.46 & 0.21 & 0.34 & 0.33 \\
\hline$D O C\left(m g l^{-1}\right)$ & 1.71 & 2.37 & 1.51 & 1.45 \\
\hline
\end{tabular}

Table 2. Annual mean values at sampling stations of Acheloos

\begin{tabular}{|c|c|c|c|c|}
\hline & Kastraki & Stratos & Dimikos & Neoxorion \\
\hline$\left.\overline{\left[N H_{4}^{+}\right](\mu g a t ~} \mathrm{Nl}^{-1}\right)$ & 0.85 & 2.31 & 0.54 & 1.33 \\
\hline$\left[\mathrm{NO}_{2}^{-}\right]\left(\mu \mathrm{gat} N l^{-1}\right)$ & 0.13 & 0.12 & 0.27 & 0.39 \\
\hline$\left[\mathrm{NO}_{3}^{-}\right]\left(\mu \mathrm{gat} N \mathrm{l}^{-1}\right)$ & 12.1 & 11.7 & 20.7 & 21.1 \\
\hline $\operatorname{Org} N\left(\mu g a t N l^{-1}\right)$ & 8.77 & 12.7 & 9.84 & 15.8 \\
\hline $\operatorname{Tot} N\left(\mu g a t N l^{-1}\right)$ & 21.8 & 26.8 & 31.3 & 38.6 \\
\hline$\left[\mathrm{PO}_{4}^{3-}\right]\left(\mu\right.$ gat $\left.\mathrm{Pl}^{-1}\right)$ & 0.10 & 0.08 & 0.17 & 0.18 \\
\hline $\operatorname{Org} P\left(\right.$ gat $\left.P l^{-1}\right)$ & 0.17 & 0.20 & 0.23 & 0.22 \\
\hline TotP ( $\mu$ gat P l-1) & 0.27 & 0.28 & 0.40 & 0.40 \\
\hline$D O C\left(m g l^{-1}\right)$ & 1.77 & 1.44 & 1.66 & 2.16 \\
\hline
\end{tabular}

Table 3. Mean concentration of nutrients and DOC in Acheloos river (values in $\mu$ gat $\mathrm{l}^{-1}$ except for DOC where values are in $\mathrm{mg} \mathrm{l}^{-1}$ )

\begin{tabular}{|c|c|c|c|c|c|c|}
\hline & $\mathrm{NH}_{4}^{+}$ & $\mathrm{NO}_{2}^{-}$ & $\mathrm{NO}_{3}^{-}$ & $\mathrm{PO}_{4}^{3-}$ & TotP & DOC \\
\hline 2003 & 0.96 & 0.21 & 16.1 & 0.14 & 0.33 & 1.81 \\
\hline $2002^{(1)}$ & 1.79 & 3.21 & 14.6 & & & 1.79 \\
\hline $2001^{(1)}$ & 2.50 & 2.14 & 15.4 & 0.32 & & \\
\hline $1991-1995^{(2)}$ & 5.14 & 1.01 & 24.5 & & 3.14 & 2.96 \\
\hline 1990 (3) & 1.43 & 0.71 & 25.0 & & 0.65 & \\
\hline 1989 (4) & 2.08 & 0.41 & 4.61 & 0.30 & 8.10 & \\
\hline $1986-1990^{(2)}$ & 4.16 & 0.91 & 21.6 & & 1.08 & \\
\hline $1982-1986^{(3)}$ & & & 11.7 & & & 2.94 \\
\hline $1980-1985^{(2)}$ & 4.45 & 0.55 & 9.46 & & 0.96 & 2.07 \\
\hline
\end{tabular}

${ }^{1}$ :General State Laboratotry $2003,{ }^{2}:$ Dassenakis $1998,{ }^{3}:$ Koussouris $1989 a,{ }^{4}:$ Gaitis 1991

Table 3. It is clear that the highest values were observed during the 90 's probably due to the rapid agricultural development of the area, those years.

On the contrary, a decrease in nutrients and DOC concentrations is observed during the last decade. The mean values measured in this work are lower than the ones of the eighties. This is an encouraging indication about the improvement of the quality of the riverine water.

\section{The river Louros}

Seasonal mean values of nitrogen and phosphorous compounds as well as dissolved organic carbon (DOC) are presented in Table 4. As extracted from Table 4, the nutrients and DOC concentrations were increased during the cold periods of the year and decreased during the warm ones with the exception of ammonia and phosphates for which the highest values were recorded during springtime. In most cases the fluctuation pattern was similar to the one of river Acheloos. 
Table 4. Seasonal mean values from all sampling stations at river Louros

\begin{tabular}{|c|c|c|c|c|}
\hline & Autumn 2002 & Winter 2003 & Spring 2003 & Summer 2003 \\
\hline $\mathrm{NH}_{4}^{+}\left(\right.$ggat $\left.\mathrm{Nl}^{-1}\right)$ & 3.25 & 2.20 & 6.39 & 4.90 \\
\hline $\mathrm{NO}_{2}^{-}\left(\mu g a t \mathrm{Nl}^{-1}\right)$ & 1.14 & 0.64 & 0.55 & 0.46 \\
\hline $\mathrm{NO}_{3}^{-}\left(\mu\right.$ gat $\left.\mathrm{Nl}^{-1}\right)$ & 75.0 & 75.6 & 70.8 & 52.2 \\
\hline $\operatorname{Org} N\left(\mu g a t N l^{-1}\right)$ & 25.7 & 15.6 & 13.0 & 8.3 \\
\hline TotN $\left(\mu g a t N^{-1}\right)$ & 105 & 94.0 & 93.1 & 65.8 \\
\hline $\mathrm{PO}_{4}^{3-}\left(\mu\right.$ gat $\left.\mathrm{Pl}^{-1}\right)$ & 0.34 & 0.21 & 0.85 & 0.36 \\
\hline $\operatorname{Org} P\left(\mu\right.$ gat $\left.P l^{-1}\right)$ & 0.26 & 0.21 & 0.11 & 0.18 \\
\hline TotP $\left(\right.$ egat $\left.P l^{-1}\right)$ & 0.60 & 0.45 & 0.83 & 0.53 \\
\hline$D O C\left(m g l^{-1}\right)$ & 1.41 & 2.84 & 1.21 & 1.41 \\
\hline
\end{tabular}

Table 5. Annual mean values of nutrients alongside the river Louros

\begin{tabular}{|c|c|c|c|c|}
\hline & Kalogiron & Vossa & St Spiridon & Petra \\
\hline$\overline{\left[\mathrm{NH}_{4}^{+}\right]\left(\mu \text { gat } \mathrm{Nl}^{-1}\right)}$ & 1.80 & 7.89 & 6.24 & 4.50 \\
\hline$\left[\mathrm{NO}_{2}^{-}\right]\left(\mu \mathrm{gat} \mathrm{Nl}^{-1}\right)$ & 0.47 & 1.13 & 1.11 & 0.51 \\
\hline$\left[\mathrm{NO}_{3}^{-}\right]\left(\mu \mathrm{gat} \mathrm{Nl}^{-1}\right)$ & 65.6 & 64.3 & 76.3 & 64.6 \\
\hline $\operatorname{Org} N\left(\mu g a t N l^{-1}\right)$ & 17.2 & 12.4 & 14.2 & 14.94 \\
\hline TotN $\left(\mu g a t \mathrm{Nl}^{-1}\right)$ & 85.1 & 85.7 & 98.9 & 84.5 \\
\hline$\left[\mathrm{PO}_{4}^{3-}\right]\left(\mu\right.$ gat $\left.\mathrm{Pl}^{-1}\right)$ & 0.21 & 0.89 & 0.63 & 0.50 \\
\hline $\operatorname{Org} P\left(\mu g a t P l^{-1}\right)$ & 0.17 & 0.18 & 0.18 & 0.23 \\
\hline TotP $\left(\mu\right.$ gat $\left.P l^{-1}\right)$ & 0.38 & 1.00 & 0.81 & 0.59 \\
\hline$D O C\left(m g l^{-1}\right)$ & 1.36 & 1.56 & 1.18 & 2.62 \\
\hline
\end{tabular}

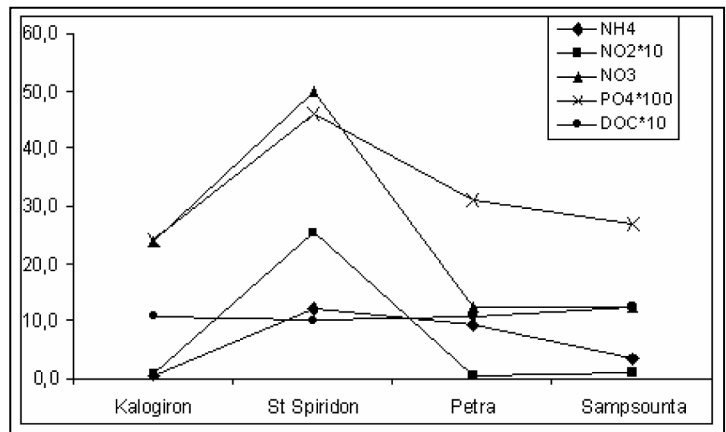

Figure 5: Concentration of nutrients and DOC along Louros during August 2003

The annual mean values of nitrogen and phosphorous compounds at the sampling stations of Louros river as well as at the small tributary of Vossa are presented in Table 5. A general increasing trend was observed between the sampling sites of Kalogiron bridge and St Spiridon bridge which does not continue thereafter. This is clear in Figure 5 where concentrations of nutrients and organic carbon alongside the river for the sampling of August 2003 are presented.

It is probable that the water of Vossa, which joins Louros between the aforementioned sampling

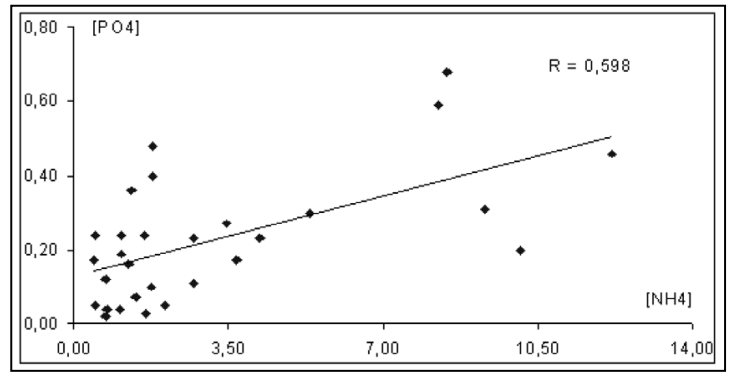

Figure 6: Correlation between [PO43-] and [NH4+] in the river Louros.

stations, often enriches the water of Louros in nutrients. The contribution of Vossa branch to the pollution of Louros is due to the existence of food industries and cattle breeding units along its sides. It is a typical case of a small river acting as a secondary pollution source for the river that accepts its water. The confluence point between Louros and Vossa can be characterized as a pollution "hot-spot" for the area.

Inorganic nitrogen dominates over organic in river Louros. Nitrates are $76 \%$ of the total, being the most important form, whereas organic nitrogen compounds are the $17 \%$.The contribution of 
Table 6. Mean concentration and range of nutrients along Louros (values in $\mu g a t \mathrm{l}^{-1}$ )

\begin{tabular}{|c|c|c|c|c|c|c|c|c|}
\hline & \multicolumn{2}{|c|}{2003} & \multicolumn{2}{|c|}{$2002^{(1)}$} & \multicolumn{2}{|c|}{$2001^{(1)}$} & \multicolumn{2}{|c|}{$1987^{(2)}$} \\
\hline & Avg & Range & Avg & Range & $A v g$ & Range & $A v g$ & Range \\
\hline$\overline{\left[\mathrm{NH}_{4}{ }^{+}\right]}$ & 3.18 & $0.01-12.2$ & 23.6 & $4.68-62.9$ & 5.00 & $2.14-7.14$ & & $0.57-8.47$ \\
\hline$\left[\mathrm{NO}_{2}^{-}\right]$ & 0.65 & $0.01-5.06$ & 1.43 & $0.00-3.57$ & 0.71 & & & $0.19-1.97$ \\
\hline$\left[\mathrm{NO}_{3}^{-}\right]$ & 66.5 & $12.4-111$ & 107 & $40.7-208$ & 121 & $106-134$ & & $14.3-25.3$ \\
\hline$\left[\mathrm{PO}_{4}^{-3}\right]$ & 0.50 & $0.02-3.05$ & 4.19 & $1.29-7.74$ & 0.32 & & & $0.08-0.99$ \\
\hline [TotP] & 0.64 & $0.19-3.05$ & 4.19 & $1.29-7.74$ & & & & $0.57-8.47$ \\
\hline
\end{tabular}

${ }^{1}$ General State Laboratory $2003,{ }^{2}$ Salta 2002

Table 7. Seasonal mean values from all sampling stations at river Acherontas

\begin{tabular}{|c|c|c|c|c|}
\hline & Autumn 2002 & Winter 2003 & Spring 2003 & Summer 2003 \\
\hline 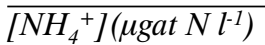 & 0.35 & 0.62 & 0.35 & 0.26 \\
\hline$\left[\mathrm{NO}_{2}^{-}\right]\left(\mu \mathrm{gat} \mathrm{Nl}^{-1}\right)$ & 0.35 & 0.19 & 0.08 & 0.13 \\
\hline$\left[\mathrm{NO}_{3}^{-}\right]\left(\mu \mathrm{gat} \mathrm{Nl}^{-1}\right)$ & 34.0 & 31.8 & 24.3 & 24.5 \\
\hline $\operatorname{Org} N\left(\mu g a t N l^{-1}\right)$ & 17.3 & 13.2 & 5.7 & 13.6 \\
\hline TotN ( & 51.9 & 45.8 & 30.5 & 38.5 \\
\hline$\left[\mathrm{PO}_{4}^{3-}\right]\left(\mu\right.$ gat $\left.\mathrm{Pl}^{-1}\right)$ & 0.15 & 0.13 & 0.11 & 0.08 \\
\hline $\operatorname{Org} P\left(\mu g a t P l^{-1}\right)$ & 26.0 & 23.0 & 15.3 & 19.3 \\
\hline 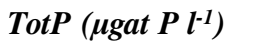 & 0.37 & 0.30 & 0.36 & 0.17 \\
\hline$D O C\left(m g l^{-1}\right)$ & 1.36 & 2.22 & 0.84 & 0.63 \\
\hline
\end{tabular}

ammonia $(5 \%)$ and nitrites $(2 \%)$ to the total nitrogen is very low.

Inorganic phosphorous also dominates over organic, being the $65 \%$ of the total.

A slight positive correlation $(\mathrm{r} \sim 0,58)$ between $\left[\mathrm{PO}_{4}^{3-}\right]$ and $\left[\mathrm{NH}_{4}^{+}\right]$(Figure 6) as well as between $\left[\mathrm{NO}_{2}^{-}\right]$and $\left[\mathrm{NO}_{3}^{-}\right]$was found by applying the appropriate statistical analysis.

The lack of sufficient correlation between various pollutants indicate (like in the case of Acheloos) various diffused and non permanent pollution sources along the river.

Although there are only poor historical data concerning the nutrients and DOC concentration in the river Louros, the data of table 6, provide useful information. It is encouraging that the concentrations of pollutants for the year 2003 were lower than for 2002 and 2001. On the other hand, ranges and maximum values of $\left[\mathrm{NH}_{4}^{+}\right],\left[\mathrm{NO}_{2}^{-}\right]$ and $\left[\mathrm{NO}_{3}^{-}\right]$for 2003 are higher than the recorded ones for 1987. It is an indication for the deterioration of the water quality in this river during the last 15 years.

\section{The river Acherontas}

Seasonal mean values of nitrogen and phosphorus compounds as well as dissolved organic carbon (DOC) are presented in Table 7.
Like in rivers Acheloos and Louros, higher values have been recorded in autumn and winter than in spring and summer. Nitrates are also the main nitrogen form in river Acherontas being the $69 \%$ of the total. Organic nitrogen is about $30 \%$, and Ammonium and nitrites less than $1 \%$ each. Organic phosphorous is the $61 \%$ of the total. Correlation was detected only in the pairs $\left[\mathrm{PO}_{4}{ }^{3-}\right]$ - $\left[\mathrm{NO}_{2}^{-}\right]$and $\left[\mathrm{PO}_{4}^{3-}\right]$ - DOC with a correlation coefficient about 0.85 .

There are not previous data concerning nutrients concentrations in river Acherontas.

A high similarity in the monthly fluctuation of chemical parameters has been recorded, between the two sampling stations. The case of phosphates is shown in figure 7.

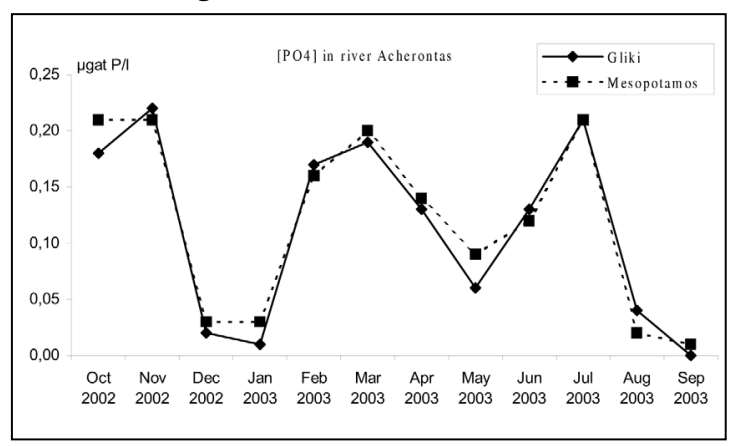

Figure 7: Fluctuation of $\left[\mathrm{PO}_{4}{ }^{3-}\right]$ in the river Acherontas. 


\section{CONCLUSIONS}

The yearly study of the temporal and spatial fluctuations and the overall geochemical behaviour of a series of significant pollutants in Acheloos, Louros and Acherontas rivers, led to some interesting conclusions about the influence of human activities, in the water quality of medium and small sized rivers, in regions like the Mediterranean basin. These systems have to be very carefully managed as they are considerably fragile. The coexistence of point and non-point polluting sources alongside these rivers in combination with the seasonal variations of river flow, of the main physicochemical parameters and of the suspended load of the rivers, affect in various ways the distribution and chemical behaviour of pollutants and lead to characteristic spatial and temporal distributions.

In small rivers, the introduction of rather low quantities of pollutants may cause significant increase of their concentrations in the neighbouring part of the river. Large fluctuations in pollutant concentrations are common in such rivers which may cause significant deterioration in the water quality and thus dangerous affect to the local ecosystems. Synergistic phenomena can also be observed. Land washout plays a very important role in the enrichment of the river water in pollutants. (GESAMP / UNESCO, 1987; GESAMP / UNESCO, 1994).

Water quality is the term which expresses the suitability of water to sustain both various human and ecological uses. The quality of rivers is classified as follows according to European Environmental Agency (EEA 1994):

Good quality: River reaches with nutrient poor water, low levels of organic matter, saturated with dissolved oxygen, rich invertebrate fauna, suitable spawning ground for salmonid fish.

Fair quality: River reaches with moderate organic pollution and nutrient content, good oxygen conditions, rich flora and fauna, large fish population Poor quality: River reaches with heavy organic pollution; oxygen concentration usually low; sediment locally anaerobic; occasional mass occurrence of organisms intensive to oxygen depletion; small or absent fish population; periodic fish kill. Bad quality: River reaches with excessive organic pollution; prolonged periods of very low oxygen concentration or total deoxygenation; anaerobic sediment; severe toxic input; devoid of fish.

Annual mean values of $\left[\mathrm{NH}_{4}^{+}\right],\left[\mathrm{NO}_{2}^{-}\right],\left[\mathrm{PO}_{4}{ }^{3-}\right]$ and organic $\mathrm{P}$, as well as $\left[\mathrm{NO}_{3}^{-}\right]$, DOC and organ- ic $\mathrm{N}$ in the three rivers are presented in figures 8 and 9 respectively. (Values are in $\mu$ gat $\mathrm{N}$ or $\mathrm{P}^{-1}$ except for the case of DOC that are in mg l-1)

According to those values, Louros is obviously the most enriched river concerning the various forms of nitrogen and phosphates. The levels of organic phosphorous are similar in all three rivers. On the other hand the highest mean value of DOC was found in Acheloos. The low values that were measured in river Acherontas indicate that this river faces the lowest environmental pressure. The water quality of Acherontas can be characterized as good, whereas of Acheloos and Louros as fair.

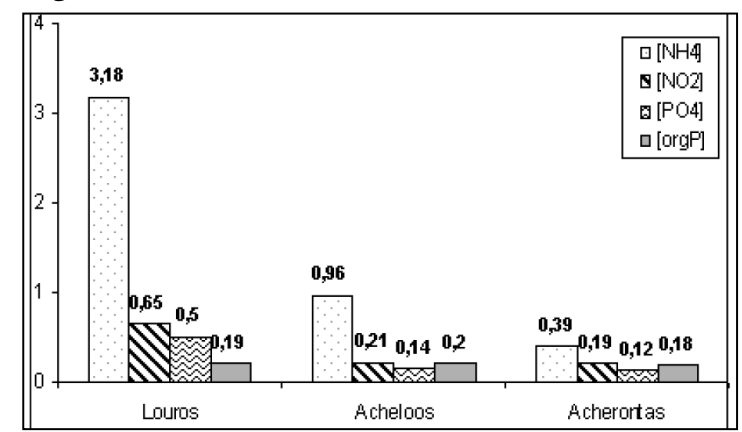

Figure 8: Annual mean values of $\left[\mathrm{NH}_{4}{ }^{+}\right],\left[\mathrm{NO}_{2}{ }^{-}\right]$, $\left[\mathrm{PO}_{4}^{3-}\right]$ and org $\mathrm{P}$

Mean values of Nitrogen and phosphorus compounds of some important Greek rivers together with the ones of the present study are presented in table 7.

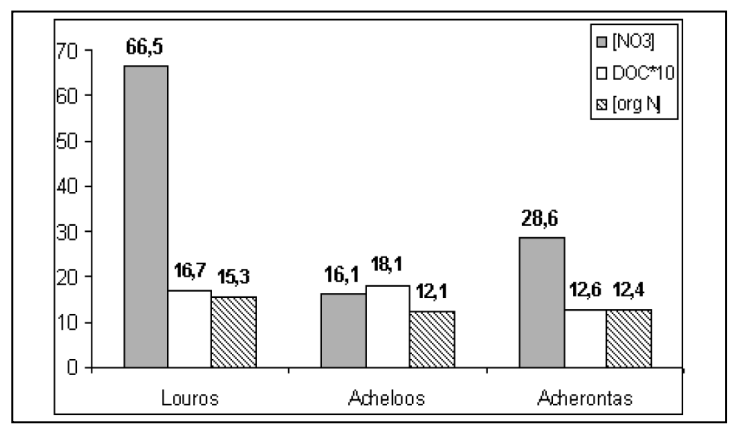

Figure 9: Annual mean values of $\left[\mathrm{NO}_{3}^{-}\right], \mathrm{DOC}$, and org $\mathrm{N}$

The Louros and Acheloos rivers and their drainage areas are affected by a lot of human activities, which introduce significant pollution loads into the rivers and result in the observation of elevated levels of pollutant concentrations that are generally higher than the maximum EEC admissible concentrations for water intended for human consumption. (European Community 
Table 8. Annual mean values of some important Greek rivers

\begin{tabular}{|c|c|c|c|c|c|c|}
\hline & {$[\mathrm{NH} 4+]$} & [NO2- & [NO3-] & Tot $\mathrm{N}$ & [PO43-] & Tot $\mathrm{P}$ \\
\hline Acheloos & 0.96 & 0.21 & 16.1 & & & 0.33 \\
\hline Aliakmonas (1990) 1 & 0.71 & 0.71 & 17.8 & & & 0.97 \\
\hline Pinios (1992) 2 & 2.83 & 1.26 & 116 & & & 2.78 \\
\hline Louros & 3.18 & 0.65 & 66.5 & 87.0 & 0.50 & 0.64 \\
\hline Acherontas & 0.39 & 0.19 & 28.6 & & & 0.30 \\
\hline Sperchios (2002) 3 & 2.88 & 2.59 & 60.8 & 96.6 & 0.70 & 0.92 \\
\hline Alfios (1993) 2 & 5.85 & 1.03 & 44.3 & & & 0.63 \\
\hline Litheos (1992) 1 & 16.4 & 7.14 & 286 & & & 11.9 \\
\hline
\end{tabular}

${ }^{1}$ Koussouris 1989b, ${ }^{2}$ Dassenakis $1998,{ }^{3}$ Salta 2002

Environmental Legislation (1992) Urban activities (waste water treatment plants, illegal disposal of wastes), hydroelectrical dams, agriculture (increased use of pesticides and fertilisers), industries or handicrafts (slaughterhouses, cheesedairies etc), without wastewater treatment plants, traffic (there are significant roads near the river) and rainwater-landwashout canals are some of them. Increased concentrations of various pollutants were measured in the neighbourhood of such activities. The river Acheloos although affected by polluting activities, is least charged in nutrients compared with rivers Aliakmonas and
Pinios. It reflects the lower economic development of Western Greece in comparison to Central and North Greece. The pollution level of Louros is similar to the one of rivers Sperchios and Alfios that are of similar size and are also affected by similar pollution sources. The mean values of nutrients concentrations in river Acherontas are generally low as it is the least affected from human activities.

The environmental quality of the studied river is generally adequate but an effective management plan must be applied in order to improve this quality.

\section{REFERENCES}

American Public Health Association, American Water Works Association, Water Pollution Control Federation (1985,) Standard Methods for the examination of water and waste water, 16th edition, pp373-404, 437-463, 556-590.

Bonazountas M., Kallidromitou D., Scoullos M., Dassenakis M., (1992), Water quality of the AetolikoMessolonghi wetlands. In Integrated Management of the Aetoliko-Messolonghi wetlands system, Final Report, Contact No ACE-2242/87/10-1,DG XI, Commission of the European Communities, Brussels.

Coste B. and Raimbault R., (1993), Recent data on the nutrient input into the Mediterranean Sea by the Rhone River. Water Poll. Research Reports, "EROS 2000", J.M. Martin and H. Barth eds, 4750.

Dassenakis M., Scoullos M., Foufa E., Krasakopoulou E., Pavlidou A., Kloukiniotou M., (1998), Effects of multiple source pollution on a small Mediterranean river, Applied Geochemistry 13, 197211.

EEA (1994) European rivers and lakes - assessment of the environmental state, Copenhagen

European Community Environmental Legislation, (1992), Council directive 80/778/EEC/15-7-1980 relating to the quality of water intended for human consumption.

Gaitis A. (1991), Study of the nutrients and trace metals levels in the estuary of Acheloos river. MSc thesis, Departement of Chemistry, University of Athens-Greece.

General State Laboratory (Greece) (2003), Results of the network for monitoring Greek surface waters GESAMP/UNESCO, (1987), Land/Sea Boundary Flux of contaminants: Contributions from rivers. Reports and Studies, 32, 67-81.

GESAMP/UNESCO, (1994), Anthropogenic influences on sediment discharge to the coastal zone and Environmental Consequences. Reports and Studies 52, 4-30.

Grasshof K. and Kremling K., (1997), Methods of Seawater Analysis, WILEY-VCH 3rd Edition. 
Greek Oceanographers Association, (1994), The water pollution monitoring in Greece. Mesopelaga, Athens, 3, 1-8.

Greek N.G.O's (WWF-Greece, Hellenic Society for the Preservation of Nature, Hellenic Society for the Protection of the Environment and the Cultural Herritage, Greek Ornithological Society), (1993). The divertion of Acheloos: a critical view on the environmental and economical impacts. Report to DG XI, E.U. Brussels.

Guieu C., Moushel J.M., Noel M.H., Guan D.M. and Martin J.M. (1991), Flux and behaviour of trace metals in the Ebro delta, Spain. Wat. Pollut. Res. Reports 28, 293-307.

Jeftic L. (1990). State of the marine environment in the Mediterranean region. MAP-UNEP Technical reports 28, 95-97

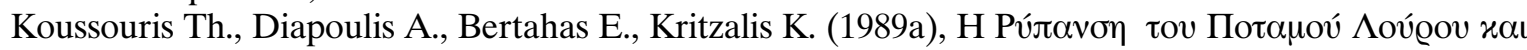

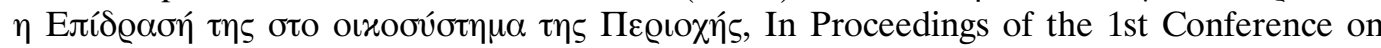
Environmental Science and Technology, Aegean University, Mytilini, Greece, A, 300-309.

Koussouris et al., (1989b), Self purification processes along a polluted river in Greece, Wat. Sci. Tech, 34, 1869-1872.

National Statistic Service of Greece (1996) Environmental Statistics 1994, Athens.

Olmez I., Beal J.W. and Villaume J.F., (1994), A new approach to understanding multiple-source groundwater contamination: factor analysis and chemical mass balances. Wat. Res. 28, 10951011.

Salta F. (2002), Nutrients and heavy metals in the area of Malliakos Gulf, MSc Thesis, Department of Chemistry, University of Athens-Greece.

Siskos P. and Skoullos M. (1992), Environmental Chemistry Volume II, University of Athens Editions, Athens.

Scoullos M., Maroulakou-Christodoulou M. and Dassenakis M., (1985), Preliminary results on the nutrient distributions in the Patraikos Gulf and the Acheloos Estuary., Rapp. Comm. Int. Mer Medit., 29 , 51-52.

Scoullos M., Dassenakis M. and Gaitis A., (1992a), Distribution of nutrients in the Acheloos river mouth, Greece, Rapp. Comm. Int. Mer Med. 33, 182.

Skoullos M. and Dassenakis M., (1992b), Chemical Oceanography laboratory handbook, 3rd Edition, University of Athens Editions, Athens.

The Greek Ministry of Agriculture, Directorate of Geology and Hydrology, (2001), Handbook for the water quality of the Greek rivers and lakes, 1, 171-207, 392-474.

The Greek Ministry of Agriculture, Directorate of Geology and Hydrology, (2001), Handbook for the water quality of the Greek rivers and lakes.

The Greek Ministry of Agriculture, Directorate of Geology and Hydrology, (2003), Handbook for the water quality of the Greek rivers and lakes, 3, 67-77, 117-124, 154-169.

The Greek Ministry for the Environment, (1989), Study of environmental impacts at the Acheloos estuary, from the divertion of the river to Thessaly, Athens.

UNEP, (1993), Preliminary assessment of the state of pollution of the Mediterranean Sea by Zinc, Copper and their compounds and proposed measures. UNEP(OCA)/MED/WG.66/Inf.3.

Ziogas G., Stamoulakis G., Constandis K. and Kalfacacou B., (1982), Pollution and Environmental problems in Ioannina area, Greece. Technical Report TEE/TH, 144. 